\section{Strong influence of geothermal heat on the physical properties of glacier ice in the Tibetan Plateau}

The Tibetan Plateau is one of the major glacierized regions in the middle to low latitudes. Based on the data of a recently completed Chinese glacier inventory (Liu and others, 2000), the areal extent of existing glaciers over the Tibetan Plateau within Chinese territory is $49873 \mathrm{~km}^{2}$, about $84 \%$ of the total area of Chinese glaciers. We report new findings of a strong influence of geothermal heat on the physical properties of glacier ice in the Tibetan Plateau.

In the boreal spring of 2004, we accessed an icefield with an area of $188.7 \mathrm{~km}^{2}$ (known as the south Geladandong flattopped glacier; Li and others, 1986) in the Geladandong region, central Tibetan Plateau. Our aim was to drill ice cores to assist in the reconstruction of past climate changes. The icefield is located in a quasi-polar glacier zone where the mean annual air temperature is $<-10^{\circ} \mathrm{C}$ and annual precipitation is $200-500 \mathrm{~mm}$ w.e. at the equilibrium-line altitude (Shi and others, 2000). This suggests the Geladandong icefield is a cold glacier. However, ice with high water content was encountered at $85.3 \mathrm{~m}$ depth at a drilling site ( $5800 \mathrm{~m}$ a.s.l.; $33^{\circ} 12^{\prime} 46^{\prime \prime} \mathrm{N}, 91^{\circ} 09^{\prime} 15^{\prime \prime} \mathrm{E}$ ) on a flat col about $1.5 \mathrm{~km}$ wide. Below that depth, we tried drilling for several runs. Each time, water flowed out from the drill tube when it was lifted to the surface, indicating the borehole contained water exuding from the surrounding ice. Since diffusion and flow of liquid water in ice can disrupt palaeoclimatic records (Rempel and others, 2001) and water in a borehole can destroy the circuit of a mechanical drilling bit, we ceased drilling at $87 \mathrm{~m}$ depth. The ice at $87 \mathrm{~m}$ was still clean and contained air bubbles similar to the ice above. We concluded the bottom of the borehole may still be some distance from the bedrock. Interestingly, no water was found in an ice core, about $189 \mathrm{~m}$ long, retrieved from Longxiazailongba glacier, about $70 \mathrm{~km}$ from the Geladandong icefield. This, together with the position of the drilling site on the Geladandong icefield, suggests that heat produced by ice deformation and sliding friction at the base is not the cause of the high water content at $85 \mathrm{~m}$ depth. It was concluded that a large geothermal heat flux may be the only reasonable explanation for this phenomenon. In fact, there are several hot springs around the margin of the Geladandong icefield, indicating the geothermal heat flux is high in this region. In another borehole only $14.6 \mathrm{~m}$ deep, drilled to bedrock on a summit (5946 ma.s.l.; measured basal temperature, $-7.25^{\circ} \mathrm{C}$ ) of the Geladandong icefield, we found no water. Presumably, there is a geothermal 'hot spot' beneath the $87 \mathrm{~m}$ borehole.

The ice temperature in the $87 \mathrm{~m}$ borehole was measured by a thermal resistance thermometer with an accuracy of $0.05 \mathrm{~K}$ (Fig. 1). The temperature at $15 \mathrm{~m}$, which has been used to reflect the mean annual air temperature (Huang, 1990 ), is $-5.00^{\circ} \mathrm{C}$, while the ice temperature at the borehole bottom is $-0.28^{\circ} \mathrm{C}$. The physical properties of the ice at the drilling site have thus led to the identification of two distinct internal layers: above $85 \mathrm{~m}$ is a cold ice layer while below $85 \mathrm{~m}$ is a wet temperate ice layer. Note there is only a small change in temperature near the bottom of the borehole measured on the first and second days after drilling ceased. A small rise in temperature near the bottom was caused by the latent heat released by refreezing of water exuded from the lower wet ice layer. The fact that the temperature sensor which reached the borehole bottom could not be retrieved testified that refreezing had occurred at the bottom. Heat flux, $H$, conducted from the lower temperate ice layer to the upper cold ice layer can be estimated by the equation

$$
H=-K \frac{\partial T}{\partial z}
$$

where $\partial T / \partial z$ ( $T$ in kelvin, $z$ in meters) is the temperature gradient in the ice immediately above the temperate layer, and $K$ is ice thermal conductivity in $\mathrm{W} \mathrm{m}^{-1} \mathrm{~K}^{-1}$. Here $\partial T / \partial z$ is calculated according to the data measured on 21 April 2004 (see Fig. 1), and $K$ can be found from the relation (Paterson, 1994)

$$
K=9.828 \exp \left(-5.7 \times 10^{-3} T\right) .
$$

Thus the inflow of heat from the lower temperate ice layer to the upper cold ice layer is about $113.5 \mathrm{~mW} \mathrm{~m}^{-2}$, which is much higher than the average continental geothermal heat flux of about $65 \mathrm{~mW} \mathrm{~m}^{-2}$ (Pollack and others, 1993). Considering the heat consumed by melting, the geothermal heat flux transmitted into the bottom ice should be much higher than the value of heat flux from the lower temperate ice layer to the upper cold layer estimated above.

More attention needs to be paid to the influence of high geothermal heat flow on glaciers. Basal meltwater and warm ice caused by high geothermal heat flow can exert a strong influence on ice flow (Fahnestock and others, 2001), and can also be responsible for glacier surface geometry (Greve and Hutter, 1995) and the response of glaciers to climate change (Hubbard and others, 2003). Even though the Geladandong icefield is large, its surface undulations seemingly depend on the land topography. This might be a consequence of an

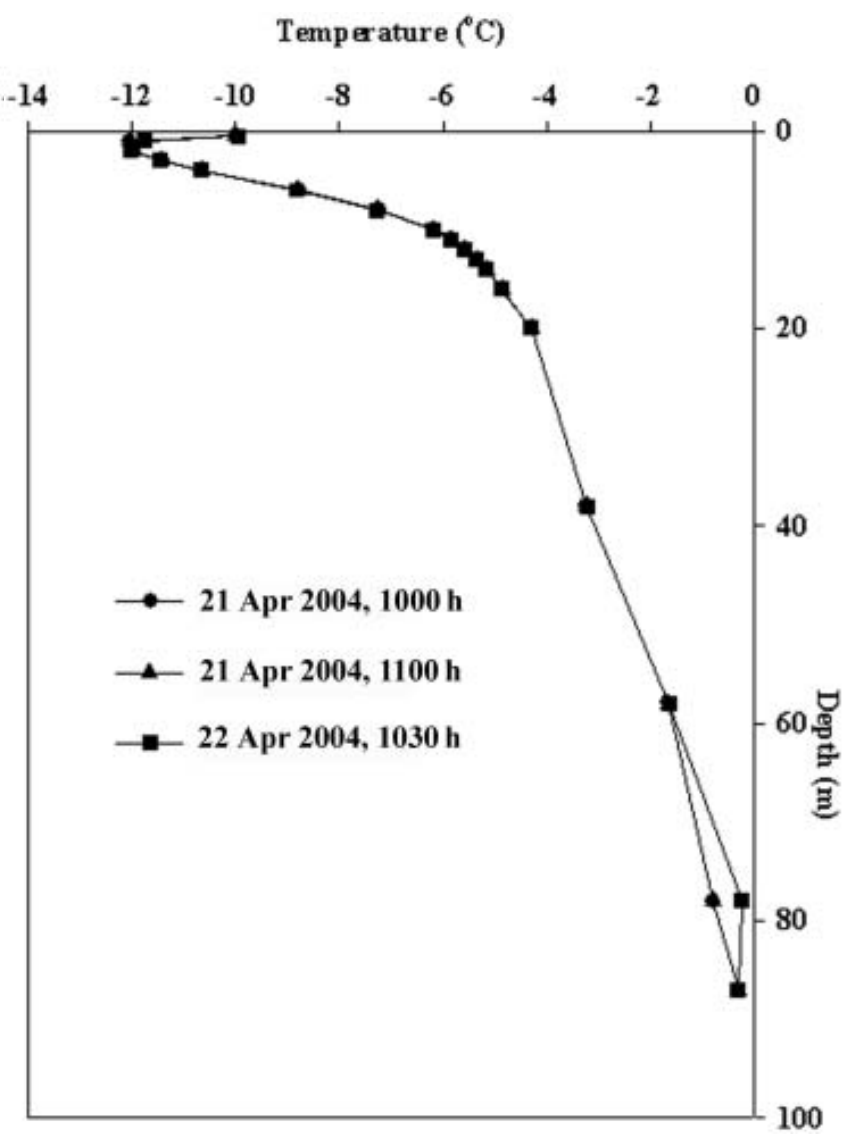

Fig. 1. Borehole temperature profiles measured at $5800 \mathrm{~m}$ a.s.I. on the Geladandong icefield, 21 and 22 April 2004. 
increase in ice 'softness' caused by high geothermal heat flux in this region. This hypothesis, and the influence of geothermal heat on glaciers, needs further investigation.

\section{ACKNOWLEDGEMENTS}

This research work is supported by the Innovation Research Project (KZCX3-SW-339-3) and the Centuria Program (2004401) of the Chinese Academy of Sciences, and the Chinese National Science Foundation (40121101).

Cold and Arid Regions Environmental

WANG Ninglian and Engineering Research Institute,

Chinese Academy of Sciences,

260 Donggang West Road,

Lanzhou 730000, China

Tibetan Plateau Research Institute,

Chinese Academy of Sciences,

Beijing 100085, China

E-mail: nlwang@ns.Izb.ac.cn

Cold and Arid Regions Environmental and Engineering Research Institute,

Chinese Academy of Sciences,

260 Donggang West Road,

Lanzhou 730000, China

23 March 2005

PU Jianchen

\section{REFERENCES}

Fahnestock, M., W. Abdalati, I. Joughin, J. Brozena and P. Gogineni. 2001. High geothermal heat flow, basal melt, and the origin of rapid ice flow in central Greenland. Science, 294(5550), 23382342.

Greve, R. and K. Hutter. 1995. Polythermal three-dimensional modelling of the Greenland ice sheet with varied geothermal heat flux. Ann. Glaciol., 21, 8-12.

Huang, M. 1990. On the temperature distribution of glaciers in China. J. Glaciol., 36(123), 210-216.

Hubbard, B.P., A. Hubbard, H.M. Mader, J.L. Tison, K. Grust and P.W. Nienow. 2003. Spatial variability in the water content and rheology of temperate glaciers: Glacier de Tsanfleuron, Switzerland. Ann. Glaciol., 37, 1-6.

Li, J. and 6 others, eds. 1986. [Glaciers in XiZang.] Beijing, Science Press. [In Chinese.]

Liu, C., Y. Shi, Z. Wang and Z. Xie. 2000. [Glacier resources and their distributive characteristics in China: a review of the Chinese glacier inventory.] J. Glaciol. Geocryol., 22(2), 106112. [In Chinese with English summary.]

Paterson, W.S.B. 1994. The physics of glaciers. Third edition. Oxford, etc., Elsevier.

Pollack, H.N., S.J. Hurter and J.R. Johnson. 1993. Heat flow from the Earth's interior: analysis of the global data set. Rev. Geophys., 31(3), 267-280.

Rempel, A.W., E.D. Waddington, J.S. Wettlaufer and M.G. Worster. 2001. Possible displacement of the climate signal in ancient ice by premelting and anomalous diffusion. Nature, 411(6837), 568-571.

Shi, Y., M. Huang and T. Yao, eds. 2000. [Glaciers and their environments in China: the present, past and future.] Beijing, Science Press. [In Chinese.] 